\title{
EFEK PEMBERIAN MINUMAN ENERGI YANG MENGANDUNG KAFEIN DAN TAURIN TERHADAP DAYA TAHAN DAN KADAR ASAM LAKTAT SAAT MELAKUKAN AKTIFITAS FISIK PADA MAHASISWA ILMU KEOLAHRAGAAN 2016
}

\author{
Oleh \\ Deni Rahman Marpaung ${ }^{1}$, Agus Salim Samosir ${ }^{1}$, Septiana M. Purba ${ }^{1}$, Khairani \\ Fitri $^{2}$ \\ ${ }^{1}$ Fakultas Ilmu Keolahragaan, Universitas Negeri Medan \\ ${ }^{2}$ Fakultas Farmasi Institut Kesehatan Helvetia \\ Email: rahmanmarpaung@gmail.com
}

\begin{abstract}
Abstrak
Tujuan dari penelitian ini adalah untuk mengetahui efek pemberian minuman energi yang mengandung kafein dan taurin terhadap daya tahan dan kadar asam laktat saat melakukan aktifitas fisik pada mahasiswa Ilmu Keolahragaan stambuk 2016. Penelitian dilakukan di Laboratorium Fitnes Universitas Negeri Medan. Penelitian ini menggunakan penelitian eksperimen, dengan metode Crossover Design. Sampel penelitian Mahasiswa Ilmu Keolahragaan Stambuk 2016 sebanyak 8 orang. Aktifitas fisik submaksimal dilakukan dengan/treadmill sampai denyut nadi submaksimal. Daya tahan di ukur dengan perbadingan waktu tempuh berlari pada pemberian air mineral dengan minuman energi dan pemeriksaan kadar asam laktat dilakukan di awal dan diakhir perlakuan. Teknik analisis data pada penelitian ini menggunakan uji-t. Hasil penelitian menunjukan Rata-rata kadar asam laktat pertemuan pertama pada kelompok I pemberian air mineral 2,225 mmol/L menjadi $5,5 \mathrm{mmol} / \mathrm{L}$ dengan waktu 39,3275 menit dan kelompok II pemberian minuman energi $2,025 \mathrm{mmol} / \mathrm{L}$ menjadi $4,025 \mathrm{mmol} / \mathrm{L}$ dengan waktu 49,6125 menit. Selanjutnya setelah di Crossover rata-rata kadar asam laktat pada pertemuan kedua untuk kelompok I pemberian minuman energi $2,725 \mathrm{mmol} / \mathrm{L}$ menjadi 4,825 mmol/L dengan waktu 53,6875 menit dan kelompok II air mineral 2,675 mmol/L menjadi 4,65 mmol/L dengan waktu 46,295 menit. Penelitian ini menyimpulkan minuman energi yang mengandung kafein dan taurin tidak dapat mempengaruhi daya tahan dan kadar asam laktat pada mahasiswa Stambuk 2016.
\end{abstract}

Kata Kunci: Kafein, Taurin, Asam Laktat

\section{A. PENDAHULUAN}

Aktifitas fisik merupakan kegiatan yang setiap saat dilakukan mulai dari bangun sampai tidur. Salah satu jenis aktifitas fisik yang dilakukan adalah dengan berolahraga. Saat melakukan aktifitas olahraga mengakibatkan kelelahan, kehabisan tenaga, dehidrasi sehingga orang mengkomsumsi makanan maupun minuman untuk mengatasi masalah tersebut. Aktivitas fisik adalah setiap gerakan tubuh yang dihasilkan oleh otot rangka yang memerlukan pengeluaran energi. Aktivitas fisik yang tidak ada (kurangnya 
aktivitas fisik) merupakan factor resiko independen untuk penyakit kronis, dan secara keseluruhan diperkirakan menyebabkan kematian secara global (WHO, 2010).

Putriastuti, et al., (2007), Kemajuan industri minuman berenergi tidak lepas dari peranan iklan sebagai media promosi kepada masyarakat Hal ini berpotensi menyebabkan efek plasebo. Efek plasebo merupakan hasil yang menyenangkan, yang diakibatkan kepercayaan bahwa seseorang telah mengalami suatu perlakuan yang bermanfaat. Untuk itu, perlu dipastikan bahwa minuman energi yang beredar di pasaran benar-benar memberikan efek yang nyata atau hanya efek plasebo

Masyarakat umum percaya bahwa dengan mengkomsumsi minuman energi dapat mengembalikan energi dengan cepat sehingga dapat melanjutkan kembali aktifitas seperti biasanya. Secara umum minuman berenergi mengandung zat stimulan seperti kafein, ekstrak herbal (seperti guarana dan ginseng), vitamin B kompleks, asam amino (contohnya taurin) dan derivat gula (Malinauskas, 2007; Nienhueser, 2009).

Minuman berenergi adalah minuman ringan yang dapat meningkatakan energi, mengurangi atau mencegah kelelahan, meningkatkan ketahanan fisik, memperbaiki mood dan kemampuan kognitif melalui stimulasi sistem metabolik dan sistem saraf pusat .Efek minuman berenergi tersebut dapat dirasakan 30-60 menit setelah pemakaian dan dipertahankan selama sekurang-kurangnya 90 menit (Duchan, 2010).

Minuman berenergi adalah minuman yang mengandung kafein, taurin, vitamin B kompleks, ekstrak herbal dan gula atau pemanis yang dapat memberikan efek yang diinginkan oleh penggunanya seperti meningkatkan energi, konsentrasi, kewaspadaan, mempertahankan kekuatan fisik, mengurangi kantuk serta membuat daya pikir menjadi lebih jernih (Seifert, 2011).

Hayati (2005), mengatakan kafein bersifat ergogenik selama latihan melalui efek langsung pada susunan saraf pusat melalui efek secara langsung pada otot rangka dengan meningkatkan transport ion calcium dan enzim regulator yang mengatur pemecahan glikogen serta metabolik dengan meningkatkan oksidasi lemak dan menurunkan oksidasi karbohidrat.

Pada penelitian Yanita McLeay et al. (2017), menunjukkan bahwa suplementasi taurine dua kali sehari selama 72 jam, memperbaiki kerusakan otot akibat latihan eksentrik dari bisep brachii pada pria sehat. ini mungkin hasil dari antioksi dan taurine 
dan peran sitoprotektif dalam otot rangka. Implikasinya terhadap taurin sebagai suplemen pemulihan Atlet yang berkompetisi dalam olahraga eksentrik.

Berdasarkan uraian di atas maka masih banyak penelitian yang menjelaskan efek pemberian minuman energi yang mengandung kafein dan taurin terhadap daya tahan dan kadar asam laktat. Jadi tujuan dari penelitian ini untuk melihat pengruh pemberian minuaman energi yang mengandung kafein dan taurin terhadap daya tahan dan kadar asam laktat pada mahasiswa Ilmu Keolahragaan 2016 Universitas Negeri Medan.

\section{B. METODE PENELITIAN}

Penelitian ini dilakukan di Laboratorium Fitnes Fakutas Ilmu Keolahragaan Universitas Negeri Medan. Secara umum rancangan penelitian ini adalah uji eksperimen dengan rancangan penelitian Crossover Design. Subjek penelitian mahasiswa Ilmu Keolahragaan Unimed, populasi penelitian ini yaitu mahasiswa Ilmu Keolahragaan Stambuk 2016 yang berjenis kelamin laki-laki berjumlah 51 orang. Sample penelitian dengan usia 19-22 tahun, dengan berat badan minimal $47 \mathrm{~kg}$ dan berat badan maksimal $65 \mathrm{~kg}$. Penelitian mengambil sample dengan cara purposive sampling yang digunakan dalam penelitian ini memiliki kriteria inklusi dan eksklusi, dengan $\mathrm{VO}_{2}$ max minimal 42,53 dan maksimal 46,544 dan telah memenuhi kriteria inklusi dan eksklusi.

Sample 8 orang dibagi dalam 2 kelompok yaitu kelompok kontrol dan kelompok eksperimen untuk di uji daya tahan dan kadar asam laktat. Setelah diberikan perlakuan maka sample di istirahatkan (wash out) selama 1 minggu, kedua kelompok saling bertukar peran (crossover) kelompok kontrol akan menjadi kelompok perlakuan dan sebaliknya.

Adapun Bahan dan Alat yang digunakan untuk daya tahan dan kadar asam laktat: Minuman energi, Aquades, Treadmill: digunakan untuk pemberian aktifitas fisik, Stop-watch: digunakan untuk membatasi waktu dan mengukur daya tahan pelaksanaan maupun perlakuan terhadap sampel, Alat tulis: untuk mencatat hasil perlakuan dan pemeriksaan pengukuran daya tahan otot dan asam laktat, BM-Lactate: stip asam laktat, cobas: untuk mengukur kadar asam laktat, Blood Lancet: jarum pengambil darah, Kapas alcohol.

Sample dibagi menjadi 2 kelompok yaitu kelompok kontrol dan kelompok eksperimen. Kedua kelompok di ambil kadar asam laktat dan pengukuran tekanan darah awal sebelum diberikan perlakuan, kemudian satu kelompok diberikan air mineral 250 
$\mathrm{ml}$ dan kelompok lain minuman energi $250 \mathrm{ml}$. Satu jam setelah pemberian dilakukan aktifitas fisik submaksimal berupa treadmill dengn kecepatan $11 \mathrm{~km} / \mathrm{jam}$. Kemudian dilakukan pengukuran daya tahan dengan mengukur waktu treadmill, kemudin dilakukan pengukuran kadar asam laktat dan tekanan darah akhir pada kedua kelompok. Setelah itu dilakukan wash out selama 1 minggu, kemudian kedua sample disilang dan dilakukan percobaan yang sama.

Data diolah dengan menggunakan program SPSS 20 dengan tingkat signifikan $\mathrm{p} \leq 0,05$ uji yang dilakukan dengan uji-t, yang didahului dengan uji Normalitas dengan Kolmogorov-Smirnov.

\section{HASIL DAN PEMBAHASAN PENELITIAN}

1. HASIL PENELITIAN

Berdasarkan hasil analisis data dengan uji Normalitas (Kolmogorov-Smirnovi) p>0,05, menunjukkan dan berdistribusi normal seperti tabel 1.

Tabel 1

Hasil Uji Normalitas Pengaruh Minuman Energi Terhadap Kadar Asam Laktat

\begin{tabular}{llcc}
\hline & \multirow{2}{*}{ Kelompok } & \multicolumn{2}{c}{ Hasil Sig. (Shapiro-Wilk) } \\
\cline { 3 - 4 } & & Pre Test & Post Test \\
\hline \multirow{2}{*}{ Pert I } & Air Mineral & 0,467 & 0,964 \\
& Minuman Energi & 0,877 & 0,599 \\
& Minuman Enerig & 0,332 & 0,133 \\
& Air Mineral & 0,260 & 0,663 \\
\hline
\end{tabular}

Keterangan: $p>0,05:$ data berdistribusi normal

Berdasarkan hasil pengukuran kadar asam laktat sebelum dan sesudah aktfitas fisik pada pertemuan I dan pertemuan II pada 8 sample penelitian, didapatkan rerata jumlah kadar asam laktat. Pertemuan I untuk kelompok I yang diberi air mineral diperoleh rata-rata kadar asam laktat pada saat pre tes 2,22 (mmol/L) dan mengalami peningkatan pada saat post tes setelah melakukan aktivitas fisik sebesar 5,55 (mmol/L). Perbedaan kadar asam laktat data pretes - posttes pada kelompok air mineral adalah sebesar 3,33 (mmol/L).

Setelah di cross over pada pertemuan II untuk kelompok I yang diberi minuman energi diperoleh rata-rata kadar asam laktat pre tes 2,02 (mmol/L) dan mengalami peningkatan pada saat post tes setelah melakukan aktivitas fisik sebesar 4,02 (mmol/L). 
Perbedaan kadar asam laktat data pretes-post tes pada kelompok minuman energi adalah sebesar 2,00 (mmol/L).

Tabel 2

Hasil Uji Normalitas Daya Tahan Kelompok I dan Kelompok II

\begin{tabular}{llc}
\hline & Daya Tahan & Hasil Sig. (Shapiro-Wilk) \\
\hline \multirow{2}{*}{ Pert. I } & Kelompok I (Air Mineral) & 0,707 \\
& Kelompok II (Minuman Energi) & 0,390 \\
\multirow{2}{*}{ Pert. II } & Kelompok I (Minuman Energi) & 0,846 \\
& Kelompok II (Air Mineral) & 0,870 \\
\hline
\end{tabular}

Keterangan: $p>0,05:$ data berdistribusi normal

Berdasarkan uji normalitas kadar asam laktat dan daya tahan berdistri busi normal karena nilai probabilitas (p) lebih besar dari 0,05 ( $\mathrm{p}>0,05)$

Tabel 3

Efek Minuman Energi Terhadap Peningkatan Kadar Asam Laktât

\begin{tabular}{llll}
\hline & Kadar Asam Laktat & Rerata \pm SD & Nilai p \\
\hline Pert I & Klpk I (Air Mineral) & $5,50 \pm 0,725$ & 0,075 \\
& Klpk II (Minuman Energi) & $4,02 \pm 1,161$ & \\
Pert II & Klpk I (Minuman Energi ) & $4,82 \pm 0,801$ & \multirow{2}{*}{0,792} \\
& Klpk II (Air Mineral ) & $4,65 \pm 0,981$ & \\
\hline
\end{tabular}

Keterangan: $p<0,05$ tidak signifikan

Berdasarkan hasil uji statistik untuk peningkatan kadar asam lakta saat melakukan aktifitas fisik pada pertemuan I dan II dimana p sebesar 0,075 dan 0,792 $(\mathrm{p}<0,05)$ berarti dapat disimpulkan bahwa terdapat perbedaan yang tidak bermakna (tidak signifikan).

Tabel 4

Efek Minuman Energi Terhadap Daya Tahan

\begin{tabular}{clll}
\hline & Daya Tahan & Rerata \pm SD & Nilai p \\
\hline \multirow{2}{*}{ Pert I } & Klpk I (Air Mineral) & $39,33 \pm 5,620$ & \multirow{2}{*}{0,155} \\
\cline { 2 - 3 } & Klpk II (Minuman Energi) & $49,61 \pm 11,310$ & \\
\hline \multirow{2}{*}{ Pert II } & Klpk I (Minuman Energi ) & $53,69 \pm 6,306$ & \multirow{2}{*}{0,270} \\
\cline { 2 - 3 } & Klpk II (Air Mineral ) & $46,29 \pm 10,394$ & \\
\hline
\end{tabular}

Keterangan: $\mathrm{p}<0,05$ tidak signifikan

Berdasarkan hasil uji statistik untuk peningkatan kadar asam lakta saat melakukan aktifitas fisik pada pertemuan I dan II dimana p sebesar 0,155 dan 0,270 $(p>0,05)$ berarti dapat disimpulkan bahwa terdapat perbedaan yang tidak bermakna (tidak signifikan) seperti tercantum pada tabel 3 dan gambar 1. 


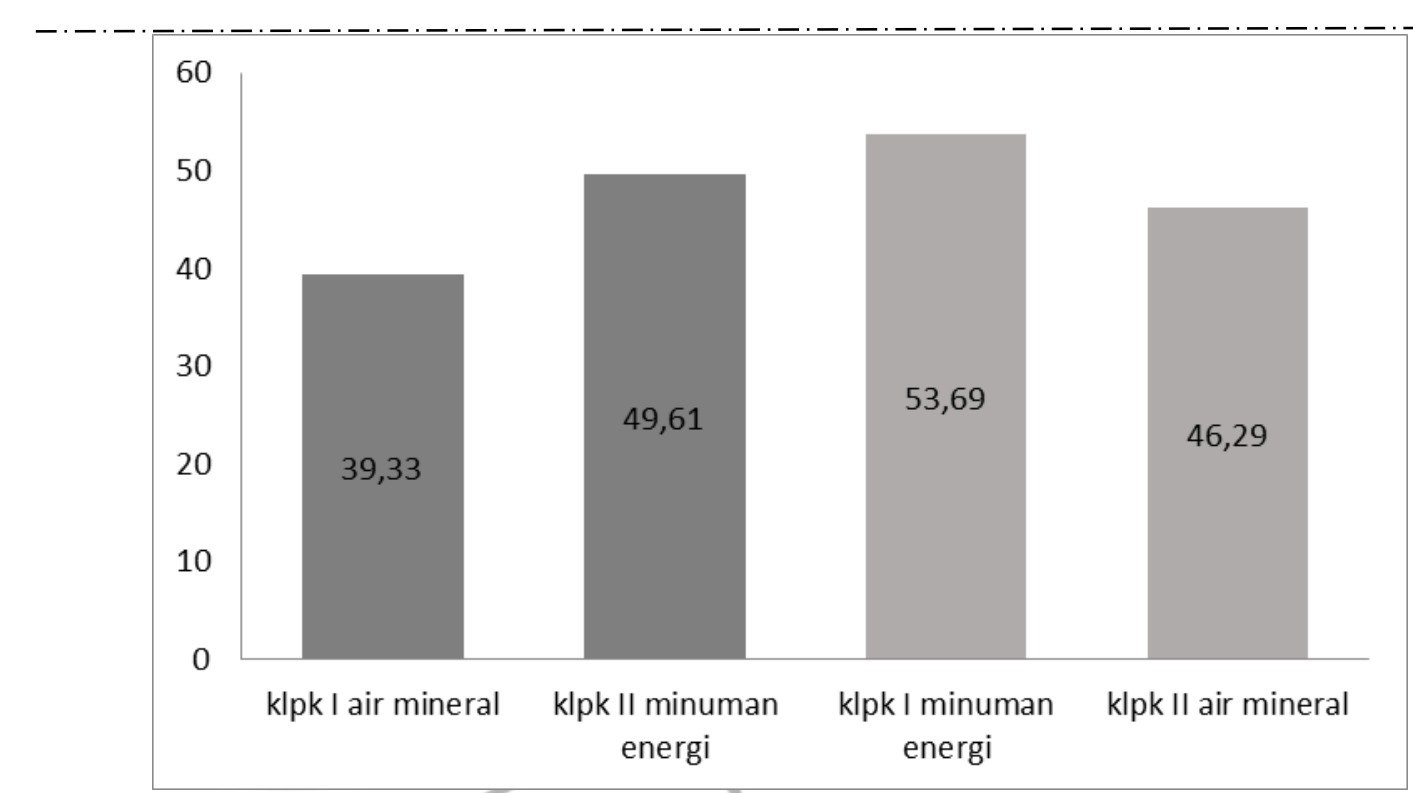

Gambar. 1 Rerata daya tahan pada pertemuan I dan pertemuan II

\section{PEMBAHASAN PENELITIAN}

Hasil uji statistik menunjukkan tidak terdapat perbedaan yang tidak bermakna terhadap peningkatan kadar asam laktat dan daya tahan setelah melakukan aktifitas fisik berupa tredmill dengan metode crossover pada kedua kelompok. Pada penelitian ini dilihat rata-rata kadar asam laktat setelah melakukan aktivitas fisik didapatkan bahwa pada pertemuan I untuk kelompok I diberi air mineral dengan kadar asam laktat ratarata sebesar 5,50 mmol/L, kelompok II yang diberi minuman energi diperoleh rata-rata sebesar 4,02 mmol/L dimana $\mathrm{p}=0,075$. Setelah di cross over pada pertemuan II untuk kelompok I diberi minuman energi dengan kadar asam laktat rata-rata sebesar 4,82 mmol/L, kelompok II yang diberi air mineral diperoleh rata-rata sebesar 4,65 mmol/L $\mathrm{p}=0,792$. Karena nilai $\mathrm{p}>0,05$.

Rerata daya tahan setelah melakukan aktivitas fisik didapatkan bahwa pada pertemuan I untuk kelompok I diberi air mineral dengan daya tahan rata-rata sebesar 39,33 menit, kelompok II yang diberi minuman energi diperoleh rata-rata sebesar 49,61 menit. Hasil uji statistik diperoleh nilai $\mathrm{p}=0,155$. Setelah di cross over pada pertemuan II untuk kelompok I diberi minuman energi dengan daya tahan rata-rata sebesar 53,69 menit, kelompok II yang diberi air mineral diperoleh rata-rata sebesar 46,29 menit. Hasil uji statistik diperoleh nilai $\mathrm{p}=0,270$.

Asam laktat merupakan produk akhir dari proses glikolisis anaerob. Tanpa produksi asam laktat, proses glikolisis ini tidak akan dapat berjalan. Laktat merupakan 
metabolit penting pada resintesis ATP, dan penghilangan laktat dapat menjadi cara untuk mendapatkan kembali energi. Oleh karena itu, oksidasi laktat dapat berkontribusi untuk mengemat cadangan karbohidrat otot dan membantu untuk menyokong intensitas latihan dalam latihan melelahkan jangka panjang (Suh et,al 2007)

Hasil penelitian ini sejalan dengan penelitian terdahulu yang dilakukan oleh Khakim, (2015) bahwa dengan pemberian kopi tidak mempengaruhi perubahan kadar asam laktat darah pada saat aktifitas fisik. Karena dalam 20 menit setelah exercise kedua kelompok menunjukkan peningkatan yang bermakna. Meningkatnya kadar asam laktat darah disebabkan kurangnya oksigen yang tersedia akibat melakukan aktifitas fisik yang melelahkan. Pada pemberian kopi dapat mengurangi penurunan glukosa darah yang terlalu besar pada saat sedang saat melakukan aktifitas fisik maupun segera melakukan aktivitas fisik sedangkan pemberian kopi terhadap asam laktat dapat mengurangi peningkatan asam laktat terlalu tinggi.

Rianti (2014), mengatakan bahwa pemberian pisang 60 menit/sebelum latihan fisik sebanyak 150 gram atau 300 gram dapat mencegah terjadi kelelahan otot pada fase aerobik. Pisang merupakan buah yang direkomendasikan untuk para atlet karena memiliki keunggulan yaitu kombinasi kandungan karbohidrat dan vitamin B sehingga dapat menyediakan energi secara cepat. Dimana kelompok kontrol 42,40 menit, kelompok perlakuan I 44,56 menit dan perlakuan II 47,00 menit.

Penelitian oleh Herwana (2005), mengatakan bahwa pemberian minuman stimulan pada tikus terbukti dapat meningkatkan kemampuan strunggling pada kelompok eksperimen 433,43 detik dan kelompok kontrol 265,27 detik. Sedangkan kenaikan kadar asam laktat 7,71 $\mathrm{mmol} / \mathrm{L}$ pada kelompok eksperimen dan kelompok kontrol 6,46 mmol/L. Berdasarkan hasil perhitungan tidak ada perbedaan yang bermakna.

Taurin merupakan asam amino non esensial, didalam kandungan minuman berenergi mampu untuk meningkatkan performan tubuh. Hasil kadar asam laktat dari 5 responden tidak menunjukkan kelelahan yang cukup tinggi setelah istirahat selama 1 jam exercise, hal ini dilihat dari perbedaan kadar asam laktat pada saat sebelum exercise, exercise selama 15 menit dan pada saat istirahat selama 1 jam yaitu selisih $<0.07 \mathrm{mmol} / \mathrm{L}$. (Hernawati, 2013). 


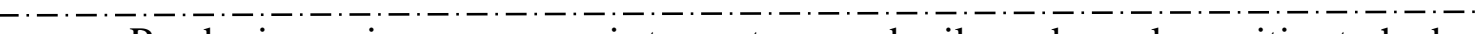

Pemberian minuman energi ternyata memberikan dampak positip terhadap penurunan kadar asam laktat, sehingga dibutuhkan waktu relative singkat untuk dapat memulihkan tenaga menjadi energi kembali. Kadar asam laktat yang tertinggi pada saat pre exercise sebesar $2.191 \mathrm{mmol} / \mathrm{L}$ dan setelah 2 istirahat sebesar $2.101 \mathrm{mmol} / \mathrm{L}$, hal ini dikarenakan subjek adalah perokok. Rata-rata dari 5 responden mengalami peningkatan kadar asam laktat cukup tinggi setelah melakukan olah raga tredmill selama 15 menit. Olahraga tredmill merupakan jenis olah raga anaerobic, pada proses metabolisme energi akan menghasilkan ATP dengan laju yang lebih cepat kurang lebih hanya sekitar \pm 90 detik ( Utomo et,al. 2018).

Purnomo (2015), mengatakan bahwa pemeberian massage setelah melakukan aktifitas fisik dapat menurunkan kadar asam laktat ini terlihat dari rerata kadar asam laktat darah maksimal dengan latihan anaerob lari 400 meter adalah sebèsar 8,3-10,4 mmol/L, sedangkan kenaikan kadar asam laktat pada kelompok massage yaitu sebesar $1,160 \mathrm{mmol} / \mathrm{L}$.

Penelitian tentang suplementasi minuman berkarbohidrat dan elektrolit pada atlet menunjukkan bahwa penurunan kadar asam laktat darah akibat lactate removal setelah latihan intensitas $70 \%$ VO2max lebih cepat secara signifikan pada suplementasi minuman elektrolit-karbohidrat $12,5 \mathrm{~g} \%$ pada 10 menit setelah latihan dan 20 menit setelah latihan terlihat dari $94,1 \pm 17,7$ dan $62,3 \pm 10,4$ menit waktu kedua kelompok (Khana. 2005)

Harahap (2017), mengatakan bahwa perlakuan jogging selama 10 menit dan berjalan (kontrol) selama 10 menit, terdapat perbedaan rata-rata penurunan kadar asam laktat dalam darah setelah latihan anaerobik (interval training). Dimana pada perlakuan jogging selama 10 menit dapat menurunkan kadar asam laktat dalam darah sebesar 4,37 $\mathrm{mMol} / \mathrm{l}$ sedangkan pada kelompok kontrol yaitu perlakuan berjalan selama 10 menit hanya terjadi penurunan sebesar 2,18 mMol/l. Dengan demikian terdapat selisih penurunan sebesar 2,19 mMol/l. Pemulihan dengan menggunakan jogging dapat mempercepat penurunan kadar asam laktat dalam darah setelah latihan anaerobik (interval training), karena asam laktat pada saat pemulihan aktif (jogging) diubah kembali menjadi energi yang dapat digunakan dalam aktivitas selanjutya.

Kafein dapat meningkatkan permukaan neurotransmiter dopamin di otak, penggunaan kafein dalam dosis terapi meningkatkan kewaspadaan, mengurangi kantuk 
dan rasa lelah, mempercepat daya berpikir, namun berkurang dalam kemampuan untuk pekerjaan yang membutuhkan koordinasi otot yang halus. gelisah, gugup, insomnia, tremor, palpitasi, dan kejang (Baumann \& Gabriel, 1984)

\section{KESIMPULAN}

Berdasarkan hasil penelitian, maka dapat ditarik kesimpulan bahwa efek minuman energi yang mengandung kafein dan taurin tidak berpengaruh signifikan terhadap penurunan kadar asam laktat dan daya tahan saat melakukan aktifitas fisik pada mahasiswa Ilmu Keolahragaan 2016.

\section{Daftar Pustaka}

Baumann, T. W., Gabriel H. 1984. Metabolism and Excretion of Caffeine During Germination of Coffea Arabica L, Plant and cell Physiology, 25 (8): 1431- 1436

Bedjo Utomo et,al. 2018. Efek Minuman Berenergi Terhadap Gambaran Sinyal Ecg Dan Kadar Asam Laktat Pada Saat Olahraga. Jurnal Penelitian Kesehatan Suara.

Brenda M Malinauskas, Victor G Aeby, Reginald/F Overton. 2007. A Survey of Energy Drink ConsumptionPatterns Among College Students, Nutr J, 6:35.

Cicip Rozana Rianti. 2014. Pengaruh pemberian pisang (musa paradisianca) terhadap kelelahan otot aerob pada atlet sepak takraw. UNDIP

Duchan E, Neil D. Patel, Cynthia F. 2010. Energy Drinks: A Review of Use and Safety DOI: 10.3810/psm.2010.06.1796.

Elly Herwana, Laurentia L. Pudjiadi. 2005. Efek Pemberian Minuman Stimulan Terhadap Kelelahan pada Mencit. Universa Medicina, 24: 8-14

Hayati. 2005. Penggunaan Kafein Dalam Dunia Olahraga Dan Efeknya Sebagai Ergogenik. PGRI

Hermawati. 2017. Produksi Asam Laktat pada exercise Aerobik dan Anerobik. Universitas Pendidikan Indonesia.

Ismail marjuki Harahap. 2015. Pengaruh Pemulihan Aktifitas (Jogging) Terhadap Penurunan Kadar Asam Laktat Dalam Darah Setelah Latihan Anaerobik (Interval Training). Universitas Negeri Semerang.

Khanna, G. L. and Manna, I. 2005. Supplementary effect of carbohydrate-electrolyte drink on sports performance, lactate removal \& cardiovascular response of athletes. The Indian Journal of Medical Research

Lukman Hakim. 2015. Efek Pemberian Kopi Terhadap Glukosa Darah Dan Laktat Darah Selama Dan Sesudah Aktifitas Fisik Submaksimal. Universitas Airlangga.

Nienhueser J, Gregory A. Brown. 2009. Effects of Energy Drinks on Resting and Submaximal Metabolism in College Age Males, Human Performance Laboratory, Department of Health and Physical Education, University of Nebraska.

Nowo Tri Purnomo. 2015. Perubahan Kadar Asam Laktat Darah Akibat Manipulasi Sport Massage Pada Laihan Aerobic. Jurnal Ilmiah Penjas. 
Sara M. Seifert, BS, Judith L. Schaechter, MD. 2011. Health Effects of Energy Drinks on Children, Adolescents and Young Adults, J Pediatrics, 7(3): 511-528, DOI:10.1542/peds.2009-3592.

Suh, S., Pail, I.Y., Jacobs, K.A,. 2007. Regulation of Blood Glucose Homeostasis during Prolonged Exercise. Mol. Cells. 2007;23(3): 272-279.

World Health Organization. 2010. Global Recommendations On Physical Activity For Health. Geneva: WHO

Yanita McLeay, Stephen Stannard and Matthew Barnes. 2017. The Effect of Taurine on the Recovery from Eccentric Exercise-Induced Muscle Damage in Males. School of Sport, Exercise, and Nutrition, Massey University.

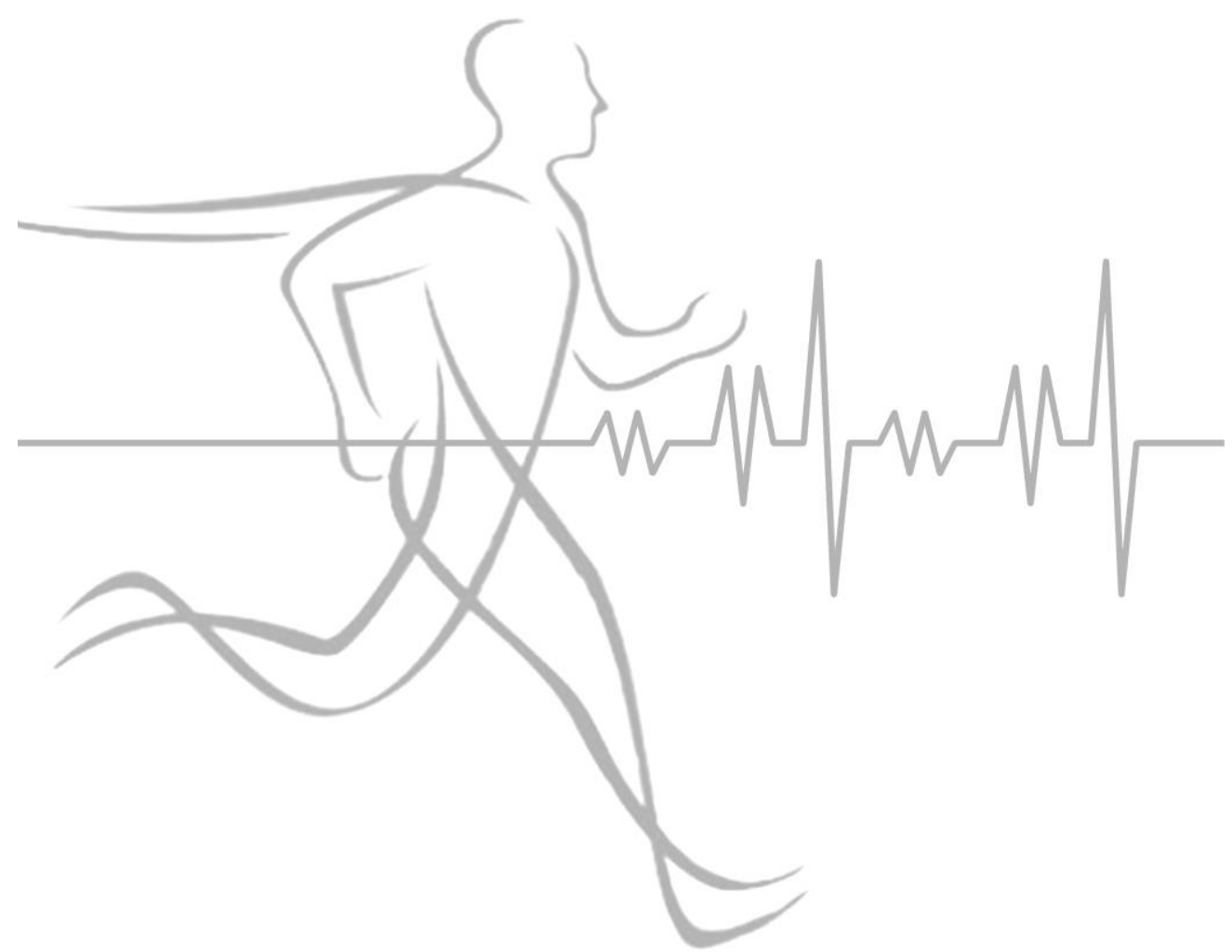

